ELORE (ISSN 1456-3010), vol. 18 - 2/2011.

Julkaisija: Suomen Kansantietouden Tutkijain Seura ry.

[http://www.elore.fi/arkisto/2_11/virtanen.pdf]

\title{
AJANKOHTAISTA
}

\section{RAJANKÄYNTIÄ MUSEOISSA}

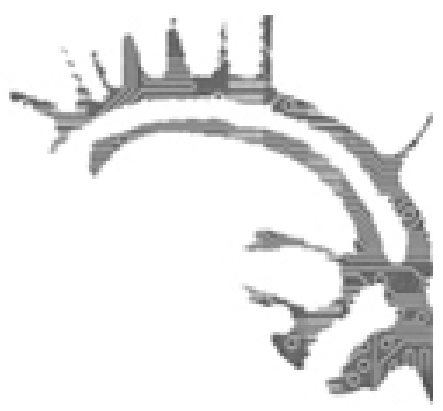

\author{
Pekka Virtanen
}

Re-Visiting the Contact Zone: Museums, Theory, Practice Lindköpingissä, Ruotsissa 17.-21.7.2011.

Dissolving boundaries. Museological approaches to national, social and cultural issues Bad Staffelsteinissa Saksassa 2.-5.10.2011.

Museolaitoksen tulevaisuuspohdinnat ovat viime aikoina olleet esillä useilla tahoilla. Tavoillaan isoja tulevaisuuksia on Suomessa pohdittu esimerkiksi Suomen Kuraattorien yhdistyksen, Museopedagogisen yhdistyksen, museologian oppiaineiden ja opiskelijatoiminnan, Museoliiton ja Museoviraston suunnilla. Eteenpäin katsottiin myös Museo- ja näyttelytutkimuksen foorumin seminaarissa Helsingissä Tieteiden talolla 6.5.2011. Artefactan Esinetutkimus nyt!-konferenssissa 6.-7.10.2011 puolestaan kartoitettiin esinetutkimuksen tilaa. Esimerkiksi jälkimmäisessä tapahtumassa olisi folkloristiikalla ollut kyllä sanansa sanottavana.

Kaiken kaikkiaan ilmassa on halua entistä tukevammin avata museon muuttuvia tehtävänkuvia, hyvänä taustana siinä myös monet uudet suomalaiset museojulkaisut. Museolaitos on periaatteessa jo nyt laaja-alaisin kulttuurilaitos dokumentoidessaan, tutkiessaan ja esitellessään ajan saatossa syntyviä ja muuttuvia kulttuurin elementtejä. Siksi pohdittavaa riittää kaikenlaisten raja-aitojen ja yhteisöllisyyden ollessa nyt ajankohtaisia kysymyksiä, rahan ohella. Viimeksi laajoja näkymiä kartoitettiin Suomessa Kangasalan Mobiliassa 24.-25.10.2011 Tulevaisunden museo-seminaarissa. Sen päämääränä oli nykykielen sanoin avata "näkökulmia ja virittää keskustelua siitä, millainen on voittajamuseon konsepti tulevaisuudessa ja millaista osaamista meillä täytyy olla ollaksemme menestyjien joukossa”.

Muun muassa kulttuurialojen tutkimuksen, opetuksen ja muun toiminnan märärahojen väheneminen sekä Guggenheim-viritykset tuovat koko museoalalle uutta säpinää. Toivottavasti kuitenkaan huippu-, inno-, diili-, sota- ja muut kilpailukäsitteet eivät ole kotiutumassa museomaailmaan. Tosin sen loppumattomista työsaroista saisi aikaan näyttävän reality-sarjan. 
Pekka Virtanen: Rajankäyntiä museoissa

\section{RAJOJA}

Museoiden tulevaisuuskeskustelua käydään vahvasti myös kansainvälisissä eri aihepiirejä käsittelevissä konferensseissa, joista osallistuin tänä vuonna omakohtaisesti kahteen, Saksassa ja Ruotsissa järjestettyyn. Saksan Baijerissa pidetyn konferenssin taustalla oli Kansainväliseen museokomiteaan kuuluva ICME (The International Committee for Museums of Ethnography), joka keskittyy etnologiaa, antropologiaa, kansatiedettä ja populaarikulttuuria lähellä olevien museoiden toimintaan. Kirjattuina tärkeinä asioina järjestö näkee muun muassa monikulttuurisuuden, muistitiedon metodit ja kulttuurin näkemisen kokonaisuutena, ei vain esineisiin keskittyen.

Valtavassa entisessä Banzin luostarissa, nykyisessä konferenssikeskuksessa 2.-5.10. 2011 järjestetty konferenssi Dissolving boundaries. Museological approaches to national, social and cultural issues oli avoinna rajoja käsitteleville papereille. Yhtenä teeman synnyttäjänä oli Saksojen yhdistyminen 20 vuotta sitten. Konkreettisia rajalinjoja availtiin konferenssissa kuitenkin vähän, enemmän tätä puolta tarkkailtiin ohjelmaan kuuluneella retkiosuudella. Sen sijaan monikulttuurisuuteen, tehtävänkuviin ja yhteisöllisyyteen liittyviä abstrakteja rajoja käsiteltiin monipuolisesti.

ICMEn konferenssissa tarinat olivat yhden session teemana. Esimerkkinä oli Rooman Piazza della Bocca Veritàn vetovoimainen turistikohde The Mouth of Truth. Alun perin veden jumaluuteen liittyvä esine on versonut tarinoita, jotka ovat kaukana sen alkuperäisestä sisällöstä. Matkailukohteen muuntuvaa luonnetta ei kuitenkaan ole lähdetty korostamaan edes museotahojen toimesta.

Näyttelymedian sisältöjä pohdittiin Bad Staffelsteinissa laajemminkin, taustaesimerkkeinä Norjan ja Ruotsin museot. Kun museonäyttelyt ovat usein harmittomia, virallista totuutta ja stereotypioita myötäileviä, niin niiden tilalla voisi olla kriittinen, epäkohtia ja uusia ajatuksia rohkeasti esiintuova ote. Kilttien "kulttuurikuvausten" sijaan yhteisöt ja ihmiset voitaisiin nähdä poliittisesti aktiivisina toimijoina, museot näyttelyineen samassa hengessä. Mutta mitä sanovat kiiltokuvista pitävät rahoittajat ja taustayhteisöt? Entä kantaaottavuutta kaihtavat tieteen tekijät?

ICMEn konferenssissa tarkkailtiin totuudenpuhumista ja museon roolia monien etnisten, sosiaalisten ja kulttuuristen yhteisöjen kautta. Amerikan intiaanit ja saamelaiset ovat tyyppiesimerkkejä tahoista, joiden kohdalla vääristymiä löytyy joka suuntaan. Matkan varrelle osunut Berliinin etnografisen museon näyttelyosuus Amerikan intiaaneista populaarikulttuurissa antoi kyllä vinkkiä, että päänahoissa on eroa ja työsarkaa yhteisöorientoituneella museolla riittää.

Irlannin Irish Travellers on esimerkki yhteisöstä, jonka dokumentointi on jäänyt vähiin. Vastaavia esimerkkejä löytyy eri näkökulmista vaikka kuinka. Ja voisiko jopa ajatella niin, että yksi kokonaisvaltaisen haarukoinnin kohde voisi olla Flaamien nationalistinen puolue Vlaams Belang, jonka näkemykset ovat täysin toisella suunnalla kuin ICMEn konferenssin päätavoitteissa rajojen ymmärtämisessä ja ylittämisessä. Belgiasta jännittävänä esimerkkinä esittelyssä oli Gentin yliopiston etnografinen nykykäsittein "maailman taiteen" kokoelma, jonka kautta on havainnoitu alkujaan "primitiivistä taidetta". Vuodesta 1825 lähtien kokoelma on palvellut monitasoisia ja täysin vastakkaisiakin identiteettejä. 
Pekka Virtanen: Rajankäyntiä museoissa

Indonesialaisin esimerkin pohdittiin yleistä näyttelykieltä, jonka ymmärtäminen ei olekaan kaikille niin itsestään selvää. Kangaskäsityöperinteestä kertova näyttely saattaa olla riittävän eksoottinen ja rikastuttava kokemus turistille. Kuitenkaan paikalliset kävijät eivät välttämättä saa tutustakaan aiheesta irti itselleen tärkeitä asioita, jos näyttelyn kerrontatapa on vieras. Toinen esimerkki Intiasta tähdensi muutosten ja luovan toiminnan esille tuomisen tärkeyttä paikallaan pysyvien ja lukittujen näyttelysisältöjen sijaan.

Torinon yliopiston antropologisen ja etnografisen museon Tongue to Tongue -näyttelyn koostamisessa oli perinteisen toteutustavan sijaan mukana yhdeksän eri etnistaustaista tekijää. Mielenkiintoista oli nähdä, kuinka esineet ja niiden kontekstit kertoivat torinolaisesta ympäristösuhteesta kovin toisenlaisia asioita kuin syntyperäisen italialaisen tai museon pitkäaikaisen kuraattorin tekemässä kattauksessa. Näyttelyn tiimoilta keskustelua syntyi.

Monikulttuurisuus, moniäänisyys, kulttuurien välisyys, yhteisöllisyys, jatkuva osallistuminen, elävä museo, moniulotteinen näyttelykieli, poikkitieteellisyys ja monet muut vastaavat käsitteet liikkuivat konferenssin esitelmissä tiuhaan. Eikä epäröity lainkaan sanoa, että hyvä museolaitos voi ottaa vahvan roolin vaikkapa afrikkalaisen kulttuurin vireänä tulkitsijana ja rakentajana.

\section{KoHTAUSPAIKKoja}

Euroopan tiedesäätiön ja Lindköpingin yliopiston 17.-21.7.2011 järjestämä konferenssi Re-Visiting the Contact Zone: Museums, Theory, Practice käsitteli museo-teemoja ICMEn konferenssia teoreettisemmin. Osallistujista moni tuli yliopistomaailmasta tai muista vastaavista tutkimusyhteisöistä, kun taas ICMEn työmaita lähempänä ovat museotoiminnan arkipäivän käytännöt, yleiseltä painoarvoltaan ei teoriaa lainkaan kevyempinä.

Euroopan tiedesäätiö on 30 maan ja lähes 80 tieteen käsikynkässä kulkevan järjestön yhteenliittymä. Sen yhtenä päämääränä on rohkaista eurooppalaisia tutkijoita keskustelemaan ja verkostoitumaan tärkeäksi katsottujen teemojen äärelle. Kesän konferenssi Lindköpingissä taisi olla tiedesäätiön ensimmäinen museoalaan liittyvä tapahtuma.

Contact Zone (CZ) on alkujaan Mary Louise Prattin 1990-luvun alussa esiintuoma käsite ilmentämään kohtauspistettä, jossa maantieteellisesti, historiallisesti, sosiaalisesti, kulttuurillisesti tai muuten ryhmiteltyjä eri tahoja edustavat ihmiset ajatuksineen kohtaavat. Kulttuuritörmäyksistäkin voisi puhua. Myöhemmin James Clifford kehitteli ajatusta edelleen erityisesti museomaailmaan soveltaen. Kummankin suuntaan Lindköpingissä viittailtiin usein, samalla käsitteen alaa kriittisesti punniten ja siitä esimerkiksi uuskolonialistisia vivahteita riisuen. Tähdennettiin myös sitä, että Contact Zonen piiriin pitää kuulua myös kritiikki ja konfliktit, voisi jopa puhua Conflict Zonesta. Vähemmin konferenssissa kiinnitettiin huomiota vuorovaikutteisiin moniarvoisuutta ja ylimaailmallisuutta sisältäviin prosesseihin. Saavutettavuuden ja eri ikäryhmien väliset ongelmat ovat olleet hyvin esillä Suomessa, mutta nämä jäivät Ruotsissa vähemmälle huomiolle. 
Lindköpingin aihepiirit sivusivat usein Norjan Utöyan tapahtumien yleisiä taustoja: miten ihmiset ja kulttuurit saadaan kohdakkain riittävän sopuisasti. Muutama päivä myöhemmin järjestettynä konferenssi olisi varmasti saanut toisenlaisen luonteen, eikä vain norjalaisten osallistujien taholla.

Lindköpingissä esiteltiin lukuisia esimerkkejä museoiden kokoelmiin, näyttelyihin, tapahtumiin ja muihin toimintoihin liittyvistä CZ-teemoista. Toisilleen kaukaisiakin tahoja yhdistävä nettimaailma koettiin tietenkin tärkeäksi. Kurkottelussa meinaa yleensä elokuvat, kirjat ja muut perinteiset formaatit unohtua paitsi osana museomediaa, myös omina riippumattomina alueinaan. Lindköpingissä ei kuitenkaan eksytty ylenpalttiseen digihehkutteluun.

Monia kertoja myönnettiin, että museot ovat tehneet paljon edesauttaakseen ihmisten, ryhmien ja kulttuurien välistä vuoropuhelua. Mutta ovatko kohtaamiset kuitenkin olleet enemmän yksisuuntaisia ja neutraaliksi pakotettuja? Ovatko akateemisuus, opettaminen, näytteillepano, arvottaminen, keruu, rahoituskäytänteet ja muut museokulttuurin osa-alueet juurtuneet liian syvälle ja niin näkymättömiin, ettei jatkuvaa vuorovaikutussuhdetta saada syntymään? Nykytaidetta ja "vieraita" kulttuureja on kyllä yritetty tehdä tutuiksi, mutta onko kyse enemmän sivistys- ja valistustyöstä kuin molemminpuolisesta ymmärtämisen halusta?

Suomessa välillä kovasti parjatut tai ainakin aliarvostetut harrastus-, kotiseutu- ja ite-museot voi nähdä tärkeinä kohtauspaikkoina. Ne edustavat vaihtoehtoista kertomisen tapaa ja asiantuntemusta, jotka sopii kohdata myös ilman akateemista ja museoammatillista ylemmyyttä. Millaisiahan kotiseutukattauksia saisi aikaiseksi, jos kotiseutumuseoiden pohjalle yhdistäisi CZ-konferenssissa esiin tulleiden esimerkkien vilauttamat monikulttuuriset näkymät, kebabpaikkoja unohtamatta?

Mielenkiintoiselta tuntui Mostarin kaupungissa meneillään oleva perinteenkeruuprojekti, jossa uudet näkökulmat pyritään kokoamaan yhteen aikaisempien aineistojen kanssa ja samalla liittämään osaksi tämän päivän keskustelua. Haasteita kyllä Mostarin tapaisessa sodan runtelemassa paikassa riittää.

Toisenlaisia vuorovaikutuksen aluetta tuotiin esiin Istanbulin biennaalissa kaksi vuotta sitten. Siinä näyttely koottiin perinteistä taidemuseoiden keruu- ja näyttelyhegemoniaa kyseenalaistaen antaen runsaasti tilaa länsimaiden ulkopuolelta tulevien taiteilijoiden näkemyksille.

Monissa etnografisissa ja antropologisissa museoissa kolonialististen taustojen pohtiminen on tällä hetkellä hyvin ajankohtaista. Uusien roolien löytäminen on tärkeää, mutta käynnissä on myös hankkeita palauttaa aikoinaan "ryöstettyjä" esineitä alkuperämaahansa. Kaikki museot siis pyrkivät tänään etsimään keinoja vieraiden kulttuurien, maahanmuuttajien, monikulttuurisuuden ja toiseuden tuomiseksi CZestradeille. Näyttelyt, juhlat, uusi arkkitehtuuri tai vanhan soveltaminen nykypäivään, tieteidenvälisyys ja monet muut asiat ovat pohdinnoissa. Mutta onko museoväki sittenkin samaa yhdenmielistä joukkoa, jonka sisällä kritiikkiä ja muutoksia ei sallita? Näin kysyttiin ja varsinkin konferenssin loppukeskustelussa koottu, museolaitoksen tärkeitä ja tulevia tehtävänkuvia kartoittava lista kyllä toi peliin paljon uutta ja korjattavaa.

Muutokset tapahtuvat hitaasti, ei tieteenkään saralla aina edetä kovin nopeasti. Aina muutoksia ei halutakaan. Matkailun puolella konferenssin CZ-tematiikka toisi 
varmasti mielenkiintoisia näkymiä. Pariisissa jo Eiffel-tornin näkeminen on puoli matkaa. Roomassa on The Mouth of Truth, johon liittyvää tarinastoa haluttaneen kuunnella valokuvan kera mieluummin kuin puhdasta totuutta.

Hyvää museota kuvailtiin kulttuurikeskukseksi ja tarinankerrontapaikaksi, jossa eri kulttuurit ja aikakaudet etsivät toisiaan. Siinä kohtauspisteessä ei yhtä totuutta löydykään.

Taas kerran "puhtaissa museokonferensseissa" saattoi nähdä, että folkloristiikan näkökulmille olisi enemmänkin sijaa museokeskustelun ytimessä kuten monilla muillakin kulttuurintutkimuksen (ja -tekemisen) aloilla. Ruotsin ja Saksan konferenssien jatkopohdintoja ajatellen esimerkiksi tämän päivän esitystutkimuksen, kanssaolemisen ja dialogisuuden suunnilta saattaisi löytyä paljon lisävirikkeitä.

Filosofian kandidaatti Pekka Virtanen on Helsingissä työskentelevä folkloristi. 